Sepolcro in the Italian Province of Arezzo. Also during the month there was a swarm of earthquakes in the Karlsrube, Rasstat, Lauterbourg area. The swarm began on June 1 and lasted practically the whole month, the greatest shock of the series being felt on June 7 with scale VI to VII (some chimneys down) at Karlsruhe. The epicentre of this shock was near lat. $49^{\circ} 04^{\prime} \mathrm{N}$., long. $8^{\circ} 19^{\prime} \mathrm{E}$. some $9 \mathrm{~km}$. north-west of Karlsruhe, and the depth of focus has been estimated at $20-30 \mathrm{~km}$. The energy of the shocks of this swarm did not travel far, but was recorded by the seismographs at Strasbourg, Stuttgart and the Swiss observatories. Apart from the observa. tories mentioned above, reports for the month have also been received from the U.S. Coast and Geodetic Survey, Aberdeen, Beograd, Cleveland (Ohio), De Bilt, Toledo and Uccle.

\section{Galactic Noise}

R. v. D. R. Wooluey has discussed in a recent paper (Mon. Not. Roy. Astro. Soc., 107, 3 ; 1948) the theory of the origin of the galactic radiation. Since radio workers consider it short-wave radiation and spectroscopists regard it as very long-wave radiation, it is undesirable to refer to it by a name embodying any idea of wave-length, and the appropriate term 'noise' has been adopted since it can be heard on the earphones. Eddington discussed the temperature of interstellar space in "The Internal Constitution of the Stars", and estimated it at about $10,000^{\circ}$; but later he suggested that the absorption in space of ultra-violet quanta would reduce the temperature. (By temperature he meant the parameter appearing in the Maxwellian velocity distribution of the free electrons.) Woolley investigates the problems of temperature and the degree of ionization in interstellar space, and concludes that if the noise is due to free-free transitions, it must certainly come from hot regions in interstellar space and almost certainly from regions where the density is above the average. In these circumstances, if 'cold' regions, that is, regions of low hydrogen ionization, do not contribute appreciably to the noise, then an observed amount of galactic noise from a particular part of the sky implies a minimum bright hydrogen emission from that part. If observation fails to reveal this bright hydrogen emission, the only conclusion is that galactic noise is not due to free-free transitions. If the noise is due to free-free transitions, it is shown that the minimum number of $\mathrm{H} \alpha$ quanta received per sq. cm. per second per unit solid angle of the sky is within reach of observation with modern equipment.

\section{Cinematograph Films of Living Cells}

C. C. Speider (Amer. Scientist, 36, 237; 1948) describes with some very fine illustrations the results he has obtained by fast cinematography of cells inside the living animal. $\mathrm{He}$ used regenerating tail tissue of the tadpole for his observations, and shows that cellular organisation may be studied here with results which tissue cultures cannot provide. Regeneration of nerve fibres, showing the manner in which their direction and anastomosing take place, mitosis in a nerve cell and the relative movements of the two daughter nuclei, the movement of lymphocytes and diapedesis of leucocytes are among the many beautiful results of this method of observation. The salvaging of extravasated blood cell by cell by the sprouting of a lymph vessel is startling, while the movement of muscle fibres in contraction and relaxation may be followed step by step. It would seem that this method of analysis would be of great value in further studies of development, especially in the little-known differentiation of plant tissues.

\section{Tests of Mosquito Repellents}

WHEN Australian forces began campaigning during the Second World War in the highly malarious islands of the south-west Pacific area, a very urgent need was an effective mosquito repellent. Bulletin No. 213 (1947) of the Commonwealth of Australia Council for Scientific and Industrial Research describes laboratory and field tests conducted by Major R. N. McCullough and Capt. D. F. Waterhouse with this object in view. More than 125 substances were tested for use as repellents against both anopheline and culicine mosquitoes. The chief species used in these experiments were Anopheles punctulatus farauti, the yellowfever mosquito Aedes agypti, and the common pest mosquito Aedes vigilax. The work involved was a co-operative investigation between the Council for Scientific and Industrial Research and the Army. Taking all factors into account, dimethyl phthalate was by far the most satisfactory repellent tested. Also, it is almost completely odourless and has very little or no irritant effect on the skin of the hands and face, to which it is applied. A number of other synthetic and naturally occurring substances were tested with indifferent results. Many essential oils were quite ineffective, while the two most promising were too irritant to use. Pyrethrum preparations gave consistently poor results. The treatment of clothing with dimethyl phthalate prevented mosquitoes from attacking through the material, except to a very limited degree, up to 72 hours after applica. tion. As a result of these investigations of repellents, and of those on a larger scale in the United States, the manufacture of adequate quantities of dimethyl phthalate was organised and the substance made available to the Australian fighting forces in 1943, some special forces being supplied with it as early as March 1943.

\section{Control of Weeds}

Prof. G. E. Blackman, in a short paper on "Recent Developments in the Control of Weeds" (J. Roy. Hort. Soc., 73, 5; May, 1948), summarizes some useful results on the effectiveness of various selective weed-killers. Sulphuric acid gave the best control of goosegrass, Galium aparine; methylchloro-phenoxy-acetic acid gave the best kill of shepherd's needle, Scandix pecten-veneris, and common red poppy, Papaver rhoeas; and dinitro-ortho-cresol was most toxic to scentless mayweed, Matricaria inodora, but also gave control equal to the acetic acid compound of $P$. rhoeas. The use of sulphuric acid is still most effective, particularly against weeds of the onion crop. Spraying with this acid gives about 90 per cent of the yield obtained by hand weeding and hoeing, but at very much less expense in labour. Charlock is susceptible to control by growth-substance sprays at all stages from seedling to flowering, though poppies are susceptible only as seedlings.

\section{Tomato Spotted Wilt Virus}

THE disease of tomatoes caused by spotted wilt virus often shows considerable variation in severity. D. O. Norris has now shown (Bull. 202, Coun. Sci. and Ind. Res., Australia; Melbourne, 1946) that this is due to varying combinations of at least five strains of the virus. The paper describes and figures the 